\title{
Evidence of connectivity between juvenile and adult habitats for mobile marine fauna: an important component of nurseries
}

\author{
Bronwyn M. Gillanders ${ }^{1, *}$, Kenneth W. Able ${ }^{2}$, Jennifer A. Brown ${ }^{3}$, \\ David B. Eggleston ${ }^{4}$, Peter F. Sheridan ${ }^{5}$ \\ ${ }^{1}$ Department of Environmental Biology, University of Adelaide, Adelaide, South Australia 5005, Australia \\ ${ }^{2}$ Marine Field Station, Institute of Marine and Coastal Sciences, Rutgers University, 800 c/o 132 Great Bay Boulevard, \\ Tuckerton, New Jersey 08087, USA \\ ${ }^{3}$ A316 Earth and Marine Sciences Building, EE Biology, University of California, Santa Cruz, California 95064, USA \\ ${ }^{4}$ North Carolina State University, Department of Marine, Earth and Atmospheric Sciences, Raleigh, \\ North Carolina 27695-8208, USA \\ ${ }^{5}$ NOAA Fisheries, Southeast Fisheries Science Center, 3500 Delwood Beach Road, Panama City, Florida 32408, USA
}

\begin{abstract}
A critical link missing from our understanding of the nursery role of specific marine habitats is the evidence of connectivity between juvenile and adult habitats. This paper reviews and evaluates evidence of, and spatial scales for, movements from juvenile to adult habitats and it summarises the methods used to study movements. Examples include many fish families but few invertebrate taxa, and most are species of economic importance for USA and Australia. The types of juvenile habitat range from the entire estuary or shallow open coastal waters to specific habitats within estuaries or coastal waters; in some cases juvenile habitats include habitats not traditionally regarded as nursery areas (e.g. the surf zone). The duration of time spent in juvenile habitats averages 13 mo (range $8 \mathrm{~d}$ to $5 \mathrm{yr}$ ). The majority of organisms move distances of kilometres to hundreds of kilometres from juvenile to adult habitats, although the scale of movements ranged from metres to thousands of kilometres. Changes in abundance among separate habitats and the progression of size classes among separate habitats are the main methods used to infer movement and habitat connectivity. Spatial partitioning of stages of maturity, natural parasites, and a variety of artificial tagging methods have also been used. The latter will become more useful with continued developments in the miniaturisation of artificial tags. More recent studies have used natural tags (e.g. trace elements and stable isotopes) and these methods show great promise for determining movements from juvenile to adult habitats. Few studies provide good evidence for movement from specific juvenile habitats to adult habitats. Future studies need to focus on this movement to supplement data on density, growth and survival of organisms in putative nursery habitats. Such information will allow management and conservation efforts to focus on those habitats that make the greatest contribution to adult populations.
\end{abstract}

KEY WORDS: Nursery habitat $\cdot$ Adult habitat $\cdot$ Movement $\cdot$ Spatial scale $\cdot$ Temporal scale $\cdot$ Estuary Open coast $\cdot$ Review $\cdot$ Connectivity

Resale or republication not permitted without written consent of the publisher

\section{INTRODUCTION}

Organisms, organic matter and nutrients are transferred between a variety of habitats, for example, between freshwater and the ocean via estuaries, pelagic and nearshore coastal waters, and kelp beds, sea- grasses and rocky reefs (Fairweather \& Quinn 1993). Links between these habitats are most often viewed in terms of larval recruitment processes that transport propagules from pelagic to benthic environments (Underwood \& Fairweather 1989, Fairweather 1991) or as trophic transfers or relays (e.g. Kneib 1997). In a 
review of linkages between different parts of the sea, however, Fairweather \& Quinn (1993) highlighted the fact that there are relatively few studies of movement processes that link different habitats. In part, lack of studies may be due to the difficulty of tracking organisms between aquatic habitats, especially small propagules and juveniles. The potentially large spatial scale over which some linkages occur, and the fact that these linkages may be episodic and thus difficult to study, also accounts for the relatively few studies.

The horizontal transfer of organisms from juvenile to adult habitats can result in substantial movement of biomass, nutrients and energy (Deegan 1993). For example, approximately 5 to $10 \%$ of the total annual primary production of estuarine areas is exported to surrounding coastal and offshore habitats (Deegan 1993). Due in part to this high potential for export of biomass, estuarine habitats, such as seagrass meadows, marshes and mangrove forests, are frequently cited as nursery habitats. Generally, a habitat has been identified as a nursery if juvenile fish or invertebrate species occur at higher densities, suffer lower rates of predation or have higher rates of growth in this habitat than in other habitats (Beck et al. 2001). However, these criteria have not addressed whether these juvenile habitats successfully transfer the higher juvenile biomass to the adult populations (Beck et al. 2001).

Following Beck et al. (2001), a habitat is considered a nursery for juveniles of a particular species if its contribution per unit area to the production of individuals that recruit to adult populations is greater, on average, than production from other habitats in which juveniles occur. Beck et al. (2001) suggested that it is critical to measure the movement of individuals from juvenile to adult habitats, and that this is a vital missing link in our understanding of nurseries. The purposes of our paper are (1) to review and evaluate evidence for movements from juvenile to adult habitats, (2) to evaluate methods that have been used to determine this movement, and
(3) to provide information on the spatio-temporal scales of such movement. In particular, we assessed whether or not evidence exists to suggest that organisms move from any of the so-called nursery habitats (e.g. marshes, mangroves and seagrasses) to adult habitats, and describe the spatial scales over which these habitats are linked via dispersal.

\section{METHODS}

The nursery role hypothesis as stated by Beck et al. (2001) only relates to species that have at least some spatial disjunction between juvenile and adult habitats (Fig. 1). We have limited our review to such species. Juvenile habitats are areas that are used for some period of time by juveniles prior to movement to adult habitat. Adult habitats are considered to be areas where juveniles are not found and may encompass sub-adult staging areas. Movement from juvenile to adult habitats is usually associated with reproduction or an ontogenetic or seasonal habitat shift probably due to changing ratios of mortality risk to growth rate (Gilliam \& Fraser 1987, Dahlgren \& Eggleston 2000). Some juvenile habitats may fit the definition of nursery habitats. However, in this review we make no distinction between juvenile and nursery habitats because there is typically insufficient data to make this distinction (Beck et al. 2001).

We searched Aquatic Sciences and Fisheries Abstracts (Cambridge Scientific Abstracts) for the period January 1982 to October 2000 using a combination of keywords: (1) movement or migration and (2) nursery, juvenile, fish, shrimp, crab, prawn or decapod. From these searches plus our personal libraries, relevant publications that dealt with movement of organisms from juvenile to adult habitats were examined. We have generally avoided citing unpubl. papers and those in the 'grey' literature, as these are difficult to obtain and generally not available to most readers.
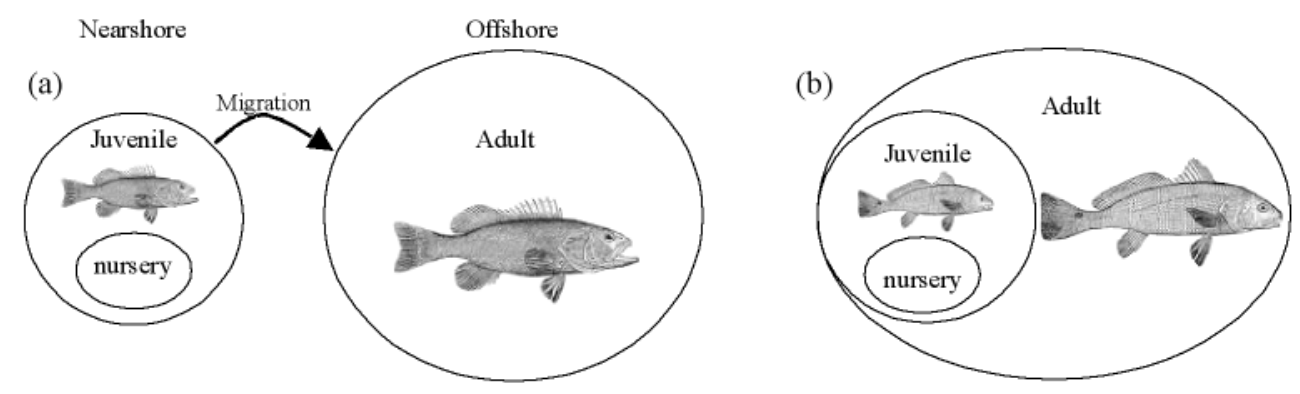

Fig. 1. Relationship between juvenile, nursery, and adult habitats. The ovals represent the portions of habitats used during juvenile and adult stages. Nursery habitats are a subset of juvenile habitats. (a) Classic concept of species that have nursery habitats, and (b) general concept of species that have nursery habitats. From Beck et al. (2001), published with permission. Copyright, American Institute of Biological Sciences 
Of the papers that met the above criteria, some were missing data that would have assisted our analyses (e.g. length of time in nursery habitats, spatial scale of movement). We have included papers in the review even if they only provide information on, for example, the length of time in the nursery habitat and no information on the spatial scale of movement. However papers were not included in the review if the distribution and population dynamics of all stages of the life history of individual species were not examined in the same study.

\section{RESULTS AND DISCUSSION}

\section{Species with separate juvenile and adult habitats}

A total of 110 studies fit our criteria and were included in this review. Most of the studies (98\%) showing movement from juvenile to adult habitats focused on fish ( $\mathrm{n}=67$ ) or decapod crustaceans ( $\mathrm{n}=41$; see Table 1$)$. The majority of studies $(78 \% ; n=41)$ examining movement of crustaceans were limited to the economically important penaeid shrimps and palinurid lobsters (e.g. Costello \& Allen 1966, Fry 1983, Booth 1986, Staples \& Vance 1986). Studies focusing on fish covered a wide range of families (e.g. Clupeidae, Labridae, Paralichthyidae, Pleuronectidae, Salmonidae, Sciaenidae, Sparidae), but again most species were of economic value. The queen conch Strombus gigas (Gastropoda), which moves from shallow sand and seagrass habitats to deeper seagrass, sand and algal habitats, was the only mollusc for which evidence of spatially segregated juvenile and adult habitats was found (Stoner et al. 1988, Stoner 1989).

Of the 110 papers reviewed, over $60 \%$ of the studies were conducted in the Northern Hemisphere; these studies covered a range of latitudes. In the Southern Hemisphere, however, almost $50 \%$ of studies were conducted in the $10^{\circ}$ latitude band between 30 and $40^{\circ} \mathrm{S}$. Within each hemisphere the majority of studies have been conducted in one country; Australia or USA. Few studies were conducted in Europe, Asia, South America or Africa (but see Benfield et al. 1990, Abello \& Macpherson 1991, Koutsikopoulos et al. 1995, Roa et al. 1995, Griffiths 1996, Yamashita et al. 2000).

Types of juvenile habitat ranged from those traditionally viewed as 'nursery' habitats - the entire estuary or specific habitats within estuaries (e.g. mangroves, marshes, seagrasses) - to habitats outside of estuaries, such as the surf zone along sandy beaches and sulphide microbial communities (Table 1). Most adult habitats were in coastal waters offshore of estuaries and included reefs, offshore regions and the continental shelf. Specific habitats within estuaries or coastal regions were not often identified.

\section{Methods for determining movement}

A variety of methods has been used to determine movement from juvenile to adult habitats (Table 2). These methods generally involve identifying changes in size- or age-structure of organisms in different habitats or sites over time either as individuals or as a group. Intrinsic (related to the real nature of the organism) and extrinsic (dependent on external circumstances) methods for measuring movement have been used (Buckley \& Blankenship 1990). Extrinsic methods may be either external, such as external tags, fin clips, external parasites, or internal, such as tags, marks or parasites that are completely enclosed within the tissues of the organism. Movement can only be measured directly by observing individually recognised or tagged organisms shifting from one place to another. Though direct measurements are preferred, much of the information on movement of juveniles comes from indirect sources, including differences in distribution, abundance and size structure, and differences in physical stages of maturity (e.g. Eggleston 1995).

\section{Distribution, abundance and size structure}

A total of 101 studies suggest movement from juvenile to adult habitats. A majority of these studies (55\%) relied on changes in abundance among separate habitats or a progression of size classes among the separate habitats to document movement (Table 2). However, there are many problems associated with measuring movement using these methods. One such problem is under-sampling of the juvenile and adult habitats. For example, some studies have sampled only one location in each of the juvenile and adult habitats and have assumed a size progression between the 2 habitats. In other studies, only one type of juvenile habitat (e.g. seagrass) has been sampled and there is no information on whether juveniles may also occur in other habitats including part of the adult habitat (but see Gillanders 1997b). An exception to this general trend was the work of Deegan (1990) who sampled 4 locations in juvenile habitat (marsh) and 4 locations in adult habitat (open bay). Deegan (1990) found that density of Gulf menhaden Brevoortia patronus was highest in tidal creeks (average fish length 30-40 mm) and that abundances in creeks declined when fish grew to 45-50 $\mathrm{mm}$, when they likely moved to open bay areas and then offshore.

The fact that organisms have frequently been collected using different methods in each of the juvenile and adult habitats is another problem (e.g. Deegan 1990) because gear biases may influence the data. It is, however, acknowledged that the different physical 


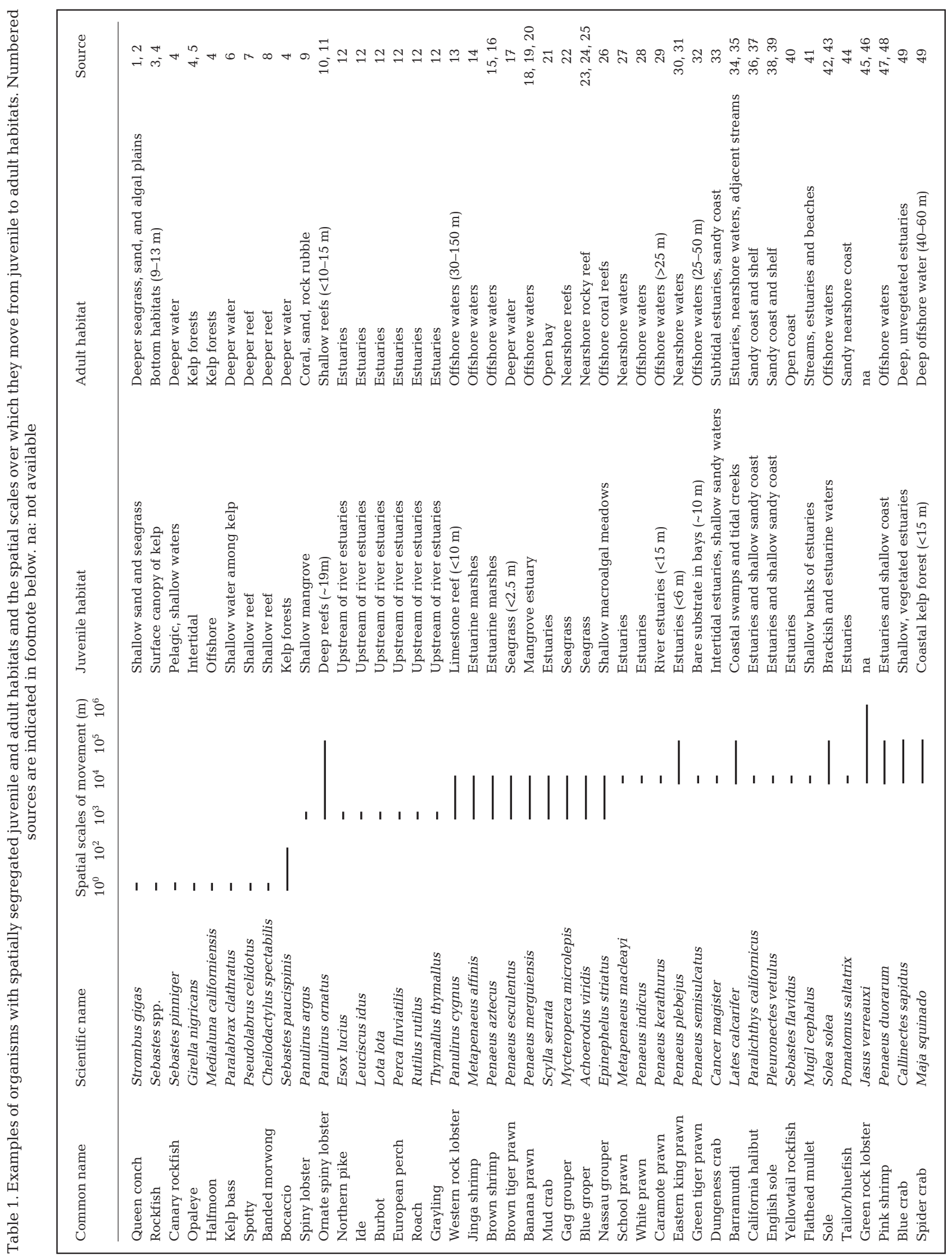




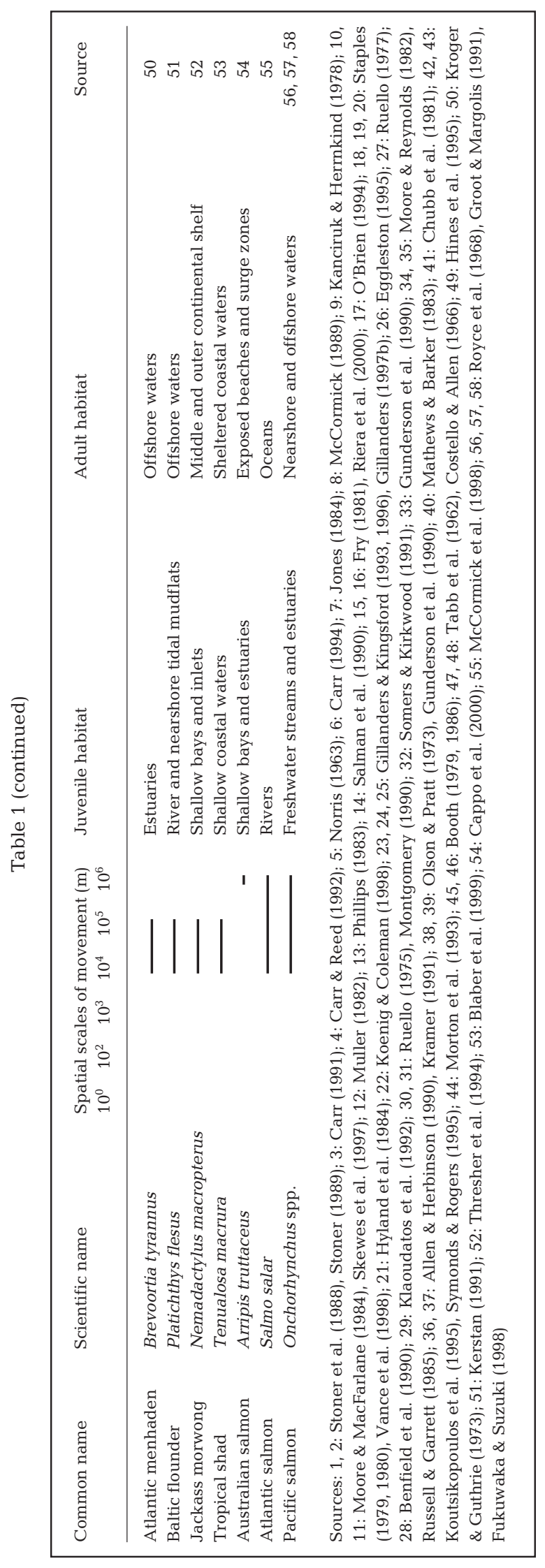

structure of some habitats means that each habitat often needs to be sampled using different methods (e.g. Blaber et al. 1989). In addition, using the same sampling method in all habitats would not necessarily alleviate this problem, because the efficiency of the same sampling technique used across a range of habitat types is seldom known (Eggleston \& Dahlgren 2001).

Differences in the distribution of size classes among different habitats have been used frequently to infer movement from juvenile to adult habitats. However, other explanations may also account for spatially explicit patterns of organism size distribution among habitats (Table 2). For example, differences in growth rates or differential mortality among habitats may result in patterns similar to those due to movement from juvenile to adult habitats. Few studies provide estimates of mortality in juvenile habitats (but see Kramer 1991, Able 1999) and it has often been assumed that movement is of primary importance (but see Sheaves 1995, Gillanders 1997a). Knowledge of the distribution of age classes among different habitats can provide complementary information to size and provide additional evidence for movement. Only a few studies have provided this additional information (e.g. Rogers 1993, Symonds \& Rogers 1995, Gillanders 1997a). As an example, spatial patterns in density and size structure of blue groper Achoerodus viridis (Labridae) showed that the proportion of small fish decreased from estuarine sites to open coastal reefs and that large fish showed the reverse pattern (Gillanders 1997b). Growth of $A$. viridis was then investigated to determine to what extent the differences in sizefrequency distributions could be explained by slower growth at estuarine reefs compared to open coastal reefs. No significant differences in growth of $A$. viridis were found and therefore spatial differences in sizefrequency distributions were most likely due to movement of fish from estuarine to coastal reefs (Gillanders 1997a).

Spatial partitioning of maturity stages was used to indicate movement from juvenile to adult habitats in 3 studies (3\%; Chong et al. 1990, Eggleston 1995, Sheaves 1995). For example, Sheaves (1995) found that only immature lutjanids (Lutjanus argentimaculatus and L. russelli) and serranids (Epinephelus coioides and E. malabaricus) were found in estuaries and that these fish were much smaller and younger than fish of the same species found offshore. Similarly, early juvenile Nassau grouper E. striatus (30 to $120 \mathrm{~mm}$ total length [TL]) use macroalgal meadows in back-reef mangrove areas, and apparently migrate to nearby patch reefs (120 to $300 \mathrm{~mm}$ TL) and eventually offshore to adult reef (>300 mm TL) 3 to 4 yr post-settlement (Eggleston 1995). In these studies, the complete ab- 
Table 2. Types of studies used to determine movement from juvenile to adult habitats, including examples

\begin{tabular}{|c|c|c|c|}
\hline Type of study & Invertebrates & Fishes & Jo. of studies \\
\hline (1) Distribution and abundance & $\begin{array}{l}\text { Stoner et al. (1988), Stoner (1989), } \\
\text { Vance et al. (1998) }\end{array}$ & $\begin{array}{l}\text { Weinstein \& Heck (1979), Kerstan } \\
\text { (1991), Dorf \& Powell (1997), } \\
\text { Henriques \& Almada (1998) }\end{array}$ & 16 \\
\hline $\begin{array}{l}\text { (2) Distribution, abundance and } \\
\text { size structure }\end{array}$ & $\begin{array}{l}\text { Gunderson et al. (1990), Salman } \\
\text { et al. (1990), Cattrijsse et al. (1997), } \\
\text { Skewes et al. (1997) }\end{array}$ & $\begin{array}{l}\text { Blaber et al. (1989), Rooker \& Dennis } \\
\text { (1991), Bell \& Worthington (1993), } \\
\text { Gillanders (1997b) }\end{array}$ & 30 \\
\hline (3) Size structure & $\begin{array}{l}\text { Coles \& Greenwood (1983), Wicker } \\
\text { et al. (1988), O'Brien (1994), Roa } \\
\text { et al. (1995) }\end{array}$ & $\begin{array}{l}\text { Shlossman \& Chittenden (1981), } \\
\text { Griffiths (1996) }\end{array}$ & 9 \\
\hline $\begin{array}{l}\text { (4) Spatial partitioning of maturity } \\
\text { stages }\end{array}$ & Chong et al. (1990) & Chong et al. (1990), Sheaves (1995) & 3 \\
\hline $\begin{array}{l}\text { (5) External tags (e.g. dart tags, } \\
\text { T-bar tags) }\end{array}$ & $\begin{array}{l}\text { Booth (1979), Hyland et al. (1984), } \\
\text { Montgomery (1990), Somers \& } \\
\text { Kirkwood (1991) }\end{array}$ & $\begin{array}{l}\text { Mathews \& Barker (1983), Morton et } \\
\text { al. (1993), Koutsikopoulos et al. (1995) }\end{array}$ & 20 \\
\hline $\begin{array}{l}\text { (6) Internal tags (e.g. microwire, } \\
\text { visual implant) }\end{array}$ & $\begin{array}{l}\text { Coded wire tags, van Montfrans } \\
\text { et al. (1991) }\end{array}$ & Ferromagnetic tags, Nicholson (1978) & 3 \\
\hline (7) Ultrasonic tags & Hines et al. (1995) & Szedlmayer \& Able (1993) & 5 \\
\hline (8) Thermal marking of otoliths & - & Urawa et al. (2000) & 1 \\
\hline $\begin{array}{l}\text { (9) Other artificial tagging } \\
\text { methods }\end{array}$ & $\begin{array}{l}\text { (e.g. marked by injection of } \\
\text { biological stains) Costello \& } \\
\text { Allen (1966) }\end{array}$ & $\begin{array}{l}\text { (e.g. freeze branding) Koenig \& } \\
\text { Coleman (1998) }\end{array}$ & 2 \\
\hline (10) Parasites as natural tags & - & Olson \& Pratt (1973) & 1 \\
\hline $\begin{array}{l}\text { (11) Stable isotopes as natural } \\
\text { tags }\left(\text { e.g. } \delta^{13} \mathrm{C}, \delta^{34} \mathrm{~S}, \delta^{15} \mathrm{~N}\right)\end{array}$ & $\begin{array}{l}\text { Fry (1981), (1983), Fry et al. (1999), } \\
\text { Riera et al. (2000) }\end{array}$ & Fry $(1983)$ & 8 \\
\hline $\begin{array}{l}\text { (12) Micro- and trace elements as } \\
\text { natural tags (e.g. Sr, Ba, Mn) }\end{array}$ & - & $\begin{array}{l}\text { Thresher et al. (1994), Gillanders \& } \\
\text { Kingsford (1996), Yamashita et al. (2000) }\end{array}$ & ) \\
\hline
\end{tabular}

sence of both post-juvenile size organisms in the juvenile habitat and juvenile size organisms in the adult habitat implied movement of organisms from the juvenile to adult habitats.

\section{Artificial tags}

Traditional tagging methods (e.g. external tags with internal attachments such as dart or T-bar tags) have been used primarily on diadromous species or on larger juveniles of marine fish species. Small organisms have generally not been tagged (see Table 3). Many of the studies using conventional tagging methods to determine movements of juveniles have different objectives than determining movement from juvenile to adult habitats. Some studies have reported limited movement, even for diadromous species, which would be expected to move large distances. For example, Russell \& Garrett (1988) found that only $2.5 \%$ of all tagged barramundi Lates calcarifer were caught away from the tidal creeks in which they were tagged. Limited movement was also found for tailor/bluefish Pomatomus saltatrix that were tagged in Morton Bay estuary (Queensland, Australia), with no fish moving outside of Morton Bay, and all fish being recaptured within $85 \mathrm{~km}$ of tagging, a relatively small distance considering the wide range of the species (Morton et al. 1993). Results suggesting limited movement may be due to the fact that recapture efforts are usually concentrated near the site(s) where tagging occurred.

Internal artificial tags, such as coded wire tags (CWT) and visible implant fluorescent elastomer (VIF), have a number of advantages over more traditional tagging methods (see Table 3 for advantages). Many hatchery-reared salmonids are tagged with CWT on release in rivers, enabling their origins to be determined when they are recaptured as either juveniles or adults at sea (Courtney et al. 2000). We are not aware of any studies that have used VIF tags to track movement of organisms from juvenile to adult habitats. Most studies using VIF tags have monitored juvenile fish over only a few months (e.g. Beukers et al. 1995, Frederick $1997 \mathrm{a}, \mathrm{b})$ or focused on larger freshwater fishes (Bonneau et al. 1995, Dewey \& Zigler 1996). Since juvenile invertebrates and fishes may spend many months in juvenile habitats before moving to adult habitats, the feasibility of using these sorts of tags may 


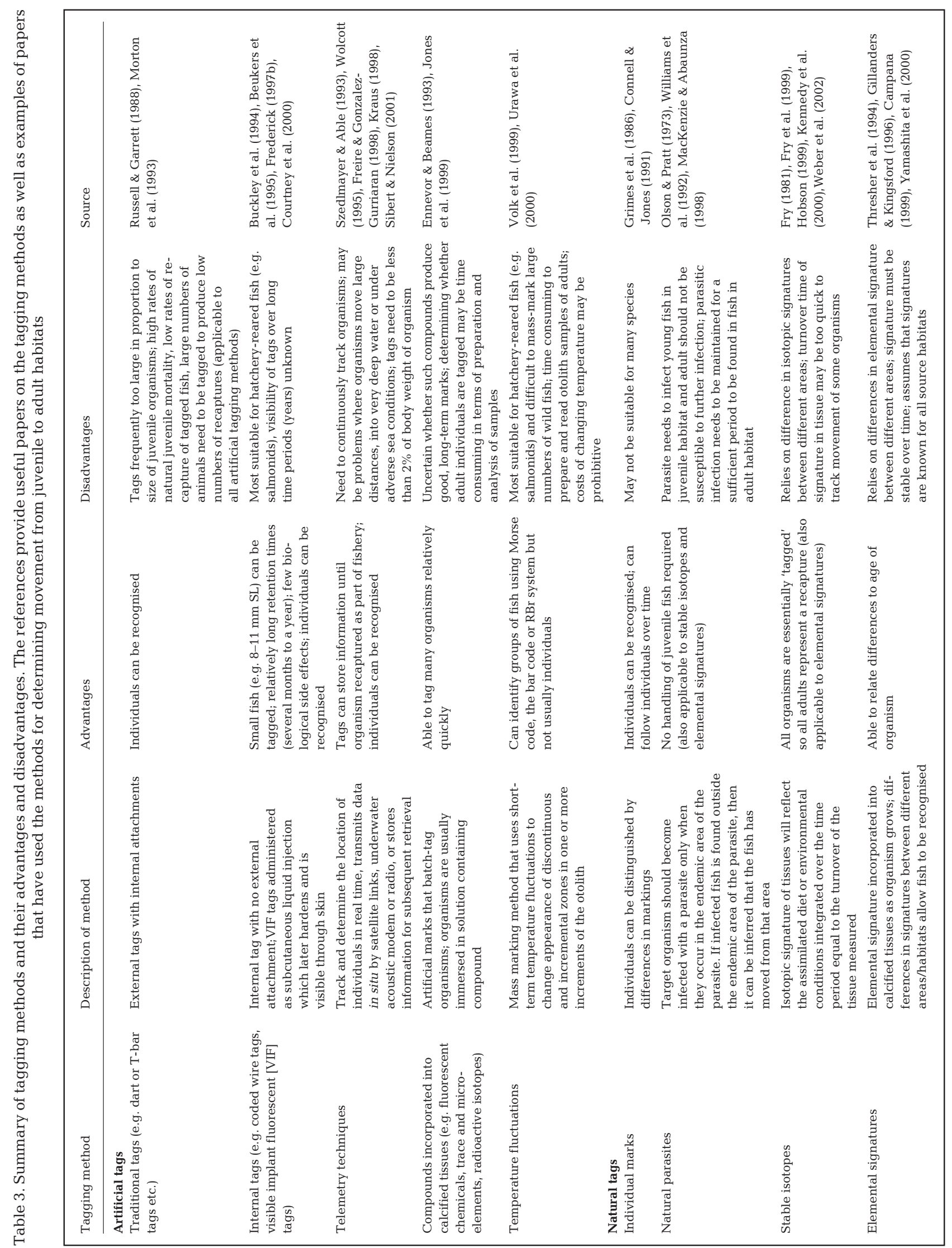


depend on the visibility of the tags over longer time periods. Juvenile organisms grow fairly rapidly and therefore it is possible that growth of surrounding tissue may limit visibility of tags.

Telemetry techniques, which track and determine the location of individuals in 'real-time', show great promise as a method to determine links between juvenile and adult habitats. Szedlmayer \& Able (1993) used ultrasonic transmitters to estimate residence time and movements of juvenile summer flounder Paralichthys dentatus in a subtidal creek. All tagged fish eventually moved out of the creek and it was suggested that this was part of a seasonal migration to the adult habitat. With continued miniaturisation of electronic components and micropower transducers, telemetry may offer a viable alternative to other artificial tagging methods for very small organisms (Sibert \& Nielson 2001). This may be especially likely with archival (e.g. West \& Stevens 2001) and pop-up tags (e.g. Block et al. 1998).

Although many of the tagging methods mentioned above allow individuals to be recognized, this may not be necessary in detecting movement from juvenile to adult habitats. Compounds that are incorporated into calcified tissues, such as fluorescent chemicals (e.g. alizarin complexone, calcein, tetracycline), trace- and micro-elements (e.g. rare earth elements, strontium) and radioactive isotopes, may be applied as artificial marks to batch tag organisms (e.g. Ennevor \& Beames 1993, Jones et al. 1999). We are not aware of any studies that have used these methods to determine movement from juvenile to adult habitats, although Jones et al. (1999) successfully used tetracycline to mark otoliths of developing embryos of a coral reef fish (Pomacentrus amboinensis) to determine whether or not populations were self-recruiting.

Temperature fluctuations have also been used to induce patterns onto otoliths as a means of massmarking (Table 3, Volk et al. 1999). The geographic origins of chum salmon from the high seas have been determined using thermal marks in otoliths (Urawa et al. 2000).

\section{Natural tags}

In an effort to overcome some problems with artificial tagging methods, alternative techniques such as natural tags have been investigated. In some instances individual marks have been used to identify marine mammals and turtles. There are a few studies that have used this approach for fishes (e.g. Grimes et al. 1986, Connell \& Jones 1991). In $12 \%$ of the studies reviewed, parasites, trace elements, and stable isotopes have been used as natural tags to determine movement from juvenile to adult habitats (e.g. Fry
1981, 1983, Thresher et al. 1994, Gillanders \& Kingsford 1996, Fry et al. 1999, Riera et al. 2000).

Natural parasites have been used as biological tags (e.g. Olson \& Pratt 1973) to detect movement from estuary to adult habitat. Olson \& Pratt (1973) found that certain parasites (e.g. the acanthocephalan, Echinorhynchus lageniformis) were acquired by English sole Pleuronectes vetulus only while in the estuary and not whilst offshore. The incidence of infection in estuarine fish before emigration was similar to the incidence in 0 -group fish collected offshore after emigration, suggesting that there was little or no influx of young from potential non-estuarine habitats (Olson \& Pratt 1973).

Stable isotopes can be used to trace the origin or movement of organisms because isotopic signatures in animal tissues reflect those of local food webs or of the aquatic habitat in which they have grown (Table 3). Isotopic signatures of food webs or water masses vary spatially depending on biogeochemical processes (Hobson 1999, Kennedy et al. 2000). The contribution of diet versus water to the isotopic signal is likely to depend on the isotope. Several studies have used a variety of stable isotopes (e.g. $\delta^{13} \mathrm{C}, \delta^{15} \mathrm{~N}, \delta^{34} \mathrm{~S}$ ) to investigate movement, including Fry (1981), who examined $\delta^{13} \mathrm{C}$ values in tissues of brown shrimp Penaeus aztecus as they moved from inshore seagrass beds to offshore areas. Offshore habitats with a phytoplankton-based food web are depleted in ${ }^{13} \mathrm{C}$ relative to a seagrassbased food web. Sub-adult individuals collected offshore had $\delta^{13} \mathrm{C}$ values typical of individuals in seagrass meadows, suggesting that they had moved from seagrass to offshore regions (Fry 1981).

Elemental signatures (e.g. $\mathrm{Sr}, \mathrm{Mn}, \mathrm{Ba}$ ) in otoliths of fish have also been used to evaluate links between juvenile areas and adult stocks (e.g. Thresher et al. 1994, Gillanders \& Kingsford 1996). The acellular and metabolically inert nature of otoliths means that many of the elements that are used as a natural tag and accreted onto the growing surface of the otolith are permanently retained (Campana 1999). The otolith continues to grow through time, ensuring that the entire lifetime of the fish has been recorded and differences in chemistry between layers can be resolved to within days or years of their deposition. The calcium carbonate and trace elements that make up $90 \%$ of the otolith are derived primarily from the water (Milton \& Chenery 2001), although there are likely to be physiological filters that prevent a simple linear relationship between the concentration of elements in the water and the otolith (Campana 1999). Analysis of either whole otoliths or small areas within the otolith have been used to distinguish stocks or sub-populations of marine species (e.g. Edmonds et al. 1989, 1991, 1992, Campana et al. 1994, Campana \& Gagne 1995, Proctor et al. 1995), to reconstruct the history of water temper- 
atures experienced by a fish throughout its life (e.g. Patterson et al. 1993), to detect anadromy (e.g. Kalish 1990, Secor 1992, Coutant \& Chen 1993) and to determine connectivity between populations (e.g. Gillanders \& Kingsford 1996, DiBacco \& Levin 2000, Yamashita et al. 2000, Thorrold et al. 2001, Gillanders 2002).

Two different approaches have been used to determine geographic origins of fish using elemental chemistry of otoliths. Gillanders \& Kingsford (1996) found significant differences in the elemental signatures of otoliths of juvenile blue groper Achoerodus viridis collected from 2 habitats: seagrass and rocky reef. The central region of adult otoliths corresponding to that laid down when the fish was a juvenile was then analysed to determine the relative importance of the 2 juvenile habitats in supporting adult stocks and to demonstrate links between juvenile and adult habitats. Conversely, Thresher et al. (1994) assessed the otolith composition at the primordium - an area corresponding to a spawning ground tag - of adult jackass morwong Nemadactylus macropterus. The samples were suggested to group into 3 offshore breeding populations. Juveniles were then collected from 2 known 'nursery' grounds and the composition of their primordial region analysed. The data from adults were then used to classify each juvenile and calculate the probability that it originated in each of the 3 breeding populations (Thresher et al. 1994).

Results from several studies indicate that juveniles from individual estuaries can be distinguished using elemental signatures (Thorrold et al. 1998, de Pontual et al. 2000, Gillanders \& Kingsford 2000), thereby suggesting that the recruitment and/or natal origins of adult fish can be determined (see Gillanders 2002). Thorrold et al. (2001) used elemental and stable isotope signatures in otoliths of weakfish Cynoscion regalis to determine natal sources and found that 60 to $81 \%$ of fish returned to natal estuaries for spawning. Swearer et al. (1999) have also used otolith chemistry to reconstruct the dispersal history of recruiting larvae. These studies demonstrate that there is much promise in using geochemical signatures to determine population connectivity such as links between juvenile and adult habitats.

\section{Spatial and temporal scales of movement}

The scale of movement from juvenile to adult habitat ranged from movements over metres (e.g. queen conch Strombus gigas, Stoner et al. 1988, Stoner 1989) to movements over thousands of kilometres (e.g. Australian salmon Arripis truttaceus; Cappo et al. 2000) (Table 1). The majority of fish and crustaceans, however, moved distances of kilometres to hundreds of kilo- metres from juvenile to adult habitats (Fig. 2, Table 1). Some organisms moved a range of scales depending on the study. For example, eastern king prawns Penaeus plebejus moved tens of kilometres in one study (Ruello 1975), but up to hundreds of kilometres in another (Montgomery 1990).

The duration of time spent in juvenile habitats ranged from days to years, but averaged $13 \mathrm{mo}$ ( $\pm 2 \mathrm{mo}$; $\mathrm{n}=67$ ). For example, juvenile blue crabs Callinectes sapidus spent as few as 8 d (but up to 65 d) in tidal marsh creeks before moving to sub-adult and adult habitats (van Montfrans et al. 1991). Similarly, adult Caribbean spiny lobster Panulirus argus move back and forth on a seasonal basis between offshore adult reef habitats where mating occurs, and inshore shallow foraging grounds during summer and fall (Lipcius \& Eggleston 2000). By comparison, yellowtail rockfish Sebastes flavidus and rock lobster Panulirus cygnus could spend up to $5 \mathrm{yr}$ in the juvenile habitat (Mathews \& Barker 1983, Phillips 1983).

Although a number of studies have shown connectivity between juvenile and adult habitats, very few have determined the relative contribution of different juvenile habitats to the adult population (e.g. Gillanders \& Kingsford 1996, Yamashita et al. 2000, Gillanders 2002). Using Sr:Ca ratios, Yamashita et al. (2000) showed that 65 and $32 \%$ of the adult stone flounder Platichthys bicoloratus population were produced from

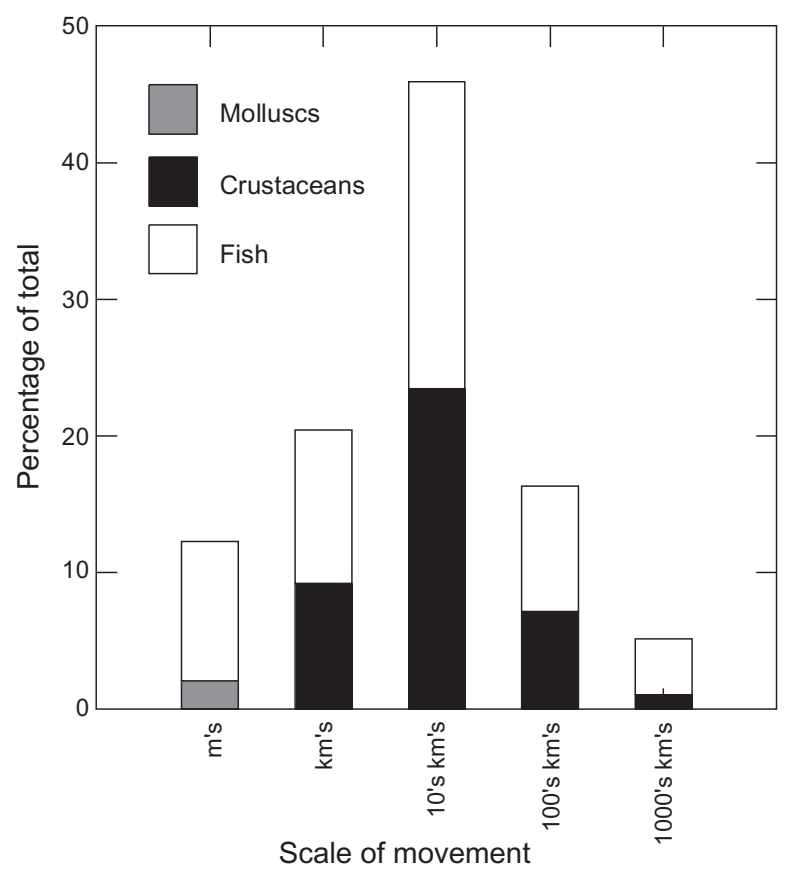

Fig. 2. Frequency histogram showing scale of movements from juvenile to adult habitats for molluscs, crustaceans and fishes $(n=98)$. The scale of movement was only indicated in some of the studies examined 
estuarine nursery areas in 1994 and 1995, respectively. The estuarine nursery grounds made up only $6 \%$ of the total nursery grounds, but juvenile density was 5 to 50 times higher in estuaries than in exposed offshore waters, indicating that estuaries are important nursery grounds (Yamashita et al. 2000). These results suggest that the relative contribution of different habitats may vary over time (e.g. among years). The contribution of different habitats or estuaries to the adult population may also vary between different regions.

\section{Management implications}

Overall, there were few studies (Table 4) that demonstrated good evidence for movement from juvenile to adult habitats. A large part of this may be due to the fact that little of the research was aimed at directly answering questions relating to this type of movement (e.g. Bell \& Worthington 1993). In addition, many studies focused either on the juvenile or adult stage of the life history, rather than on both stages. For example, many studies have sampled juvenile habitats and assumed that once organisms are no longer found there, they have moved to adult habitats. While this may be the case, it does not provide strong evidence that organisms have successfully moved to adult habitats or which juvenile habitats may contribute the most individuals to the adult population. Further, sampling was often limited to one type of habitat or to one location within each type of habitat, which restricts the conclusions that may be drawn. There is a clear need to obtain information on abundance and size distribution of organisms from a range of juvenile and adult habitats, and to sample at multiple locations within each type of habitat.

Although direct tagging is in theory the most effective method for showing movements between juvenile and adult habitats, there are problems when dealing with large numbers of wild fish that need to be tagged at a small size (see Table 3). The evidence is strongest for penaeid prawns, where individuals that were tagged in estuaries have been recaptured offshore (Ruello 1975, 1977, Montgomery 1990). Ruello (1977) found recapture rates from 0 to $7.7 \%$, depending on the estuary in which the prawns were released, suggesting that large numbers need to be tagged to make strong inferences regarding habitat linkages. Studies on fish have generally focused on tagging larger juveniles rather than smaller, newly recruited individuals.

Table 4. Studies that show good evidence of movement between juvenile and adult habitats. Spatial and temporal scales of movement between juvenile and adult habitats, and method used to determine movement is shown

\begin{tabular}{|c|c|c|c|c|}
\hline Organism & Spatial scale & Temporal scale & Method & Source \\
\hline $\begin{array}{l}\text { Queen conch } \\
\text { Strombus gigas }\end{array}$ & Tens of metres & $1-3 \mathrm{yr}$ & $\begin{array}{l}\text { Distribution and abundance, tag- } \\
\text { ging and direct observations }\end{array}$ & $\begin{array}{l}\text { Stoner et al. (1988), } \\
\text { Stoner (1989) }\end{array}$ \\
\hline $\begin{array}{l}\text { Brown shrimp } \\
\text { Penaeus aztecus }\end{array}$ & $\begin{array}{l}\text { Kilometres to tens of kilo- } \\
\text { metres }\end{array}$ & $<3 \mathrm{mo}$ & Stable isotopes $\left(\delta^{13} \mathrm{C}\right)$ & Fry (1981) \\
\hline $\begin{array}{l}\text { Pink shrimp } \\
\text { Farfantepenaeus duorarum }\end{array}$ & Tens of kilometres & $<6$ mo & Stable isotopes $\left(\delta^{13} \mathrm{C}\right.$ and $\left.\delta^{15} \mathrm{~N}\right)$ & Fry et al. (1999) \\
\hline $\begin{array}{l}\text { Pink shrimp } \\
\text { Farfantepenaeus duorarum }\end{array}$ & Not indicated & $\begin{array}{c}\text { Not } \\
\text { indicated }\end{array}$ & $\begin{array}{l}\text { Mark-recovery experiments with } \\
\text { biological stains }\end{array}$ & Costello \& Allen (1966) \\
\hline $\begin{array}{l}\text { Eastern king prawns } \\
\text { Penaeus plebejus }\end{array}$ & $\begin{array}{l}\text { Less than } 100 \mathrm{~km} \text { from juve- } \\
\text { nile to adult habitats, but up } \\
\text { to } 1000 \mathrm{~km} \text { to reproductive } \\
\text { habitat }\end{array}$ & $\begin{array}{c}\text { Not } \\
\text { indicated }\end{array}$ & Atkins-type tags (external tag) & Ruello $(1975,1977)$ \\
\hline $\begin{array}{l}\text { Eastern king prawns } \\
\text { Penaeus plebejus }\end{array}$ & $\begin{array}{l}10-160 \mathrm{~km} \text {, but up to } 1200 \mathrm{~km} \\
\text { to spawning grounds }\end{array}$ & $<3-4$ mo & Streamer tags (external tag) & Montgomery (1990) \\
\hline $\begin{array}{l}\text { Sole } \\
\text { Solea solea }\end{array}$ & $40-80 \mathrm{~km}$ & $<2 \mathrm{yr}$ & $\begin{array}{l}\text { Petersen disc attached with a } \\
\text { titanium wire just in front of } \\
\text { pectoral fin (external tag) }\end{array}$ & $\begin{array}{l}\text { Koutsikopoulos et al. } \\
\text { (1995) }\end{array}$ \\
\hline $\begin{array}{l}\text { Atlantic menhaden } \\
\text { Brevoortia tyrannus }\end{array}$ & $\begin{array}{l}\text { Kilometres to hundreds of } \\
\text { kilometres }\end{array}$ & $<1 \mathrm{yr}$ & $\begin{array}{l}\text { Numbered ferromagnetic tag } \\
(7.0 \times 2.5 \times 0.4 \mathrm{~mm})\end{array}$ & $\begin{array}{l}\text { Kroger \& Guthrie } \\
(1973)\end{array}$ \\
\hline $\begin{array}{l}\text { English sole } \\
\text { Pleuronectes vetulus }\end{array}$ & Tens of kilometres & $<1 \mathrm{yr}$ & Natural parasites & Olson \& Pratt (1973) \\
\hline $\begin{array}{l}\text { Blue groper } \\
\text { Achoerodus viridis }\end{array}$ & $\begin{array}{l}\text { Kilometres to tens of kilo- } \\
\text { metres }\end{array}$ & $3-4 \mathrm{mo}$ & $\begin{array}{l}\text { Elemental signatures (Mn, } \mathrm{Sr} \\
\text { and } \mathrm{Ba} \text { in otoliths) }\end{array}$ & $\begin{array}{l}\text { Gillanders \& Kingsford } \\
\text { (1996) }\end{array}$ \\
\hline $\begin{array}{l}\text { Stone flounder } \\
\text { Platichthys bicoloratus }\end{array}$ & Tens of kilometres & $<1 \mathrm{yr}$ & $\begin{array}{l}\text { Elemental signatures ( } \mathrm{Sr}: \mathrm{Ca} \\
\text { ratios in otoliths) }\end{array}$ & $\begin{array}{l}\text { Yamashita et al. } \\
(2000)\end{array}$ \\
\hline $\begin{array}{l}\text { Snapper } \\
\text { Pagrus auratus }\end{array}$ & $\begin{array}{l}\text { Kilometres to tens of kilo- } \\
\text { metres }\end{array}$ & $<2 \mathrm{yr}$ & $\begin{array}{l}\text { Elemental signatures (Mg, Mn, } \\
\text { Sr and } \mathrm{Ba} \text { in otoliths) }\end{array}$ & Gillanders (2002) \\
\hline
\end{tabular}


In the future, further evidence for movement from juvenile to adult habitats is likely to come from markrecapture methods using artificial tags, especially as the size of tags continues to decrease. Natural tags, such as stable isotopes and trace elements, also show great potential for determining movement from juvenile to adult habitats and are currently providing the best results (e.g. Fry 1981, Gillanders \& Kingsford 1996). Future research needs to focus on the temporal stability of such signatures and the spatial scale over which differences in signatures are found, as few studies currently address these issues.

As human activities continue to eliminate or fragment habitats, an understanding of connectivity between juvenile and adult populations becomes increasingly important. Connectivity is likely to depend not only on the distance between the 2 habitats, but also on the presence of movement corridors or stepping-stones of natural habitat. Failure to protect habitats and the capacity of fish to move freely among them may have detrimental effects on adult populations. For example, if organisms only move from juvenile to adult habitats along vegetated corridors, and do not move over unvegetated habitats, then factors contributing to degradation of vegetated habitats may also contribute to a decline of the adult populations that rely on these juvenile habitats as sources of recruits. Telemetry techniques may be most appropriate for addressing questions related to movement along corridors.

Knowledge of connectivity between juvenile and adult populations and determination of potential habitats that supply more recruits to adult populations (e.g. Fig. 4 in Beck et al. 2001) have considerable implications for fisheries management and the effective conservation of organisms. If some habitats or sites (e.g. estuaries) show strong links to adult populations, and these sites contribute to replenishing adult populations, then such sites may indicate source areas and should potentially be set aside as marine protected areas. Efforts in management and habitat conservation could also be more judiciously invested in particular sites rather than focusing on all seagrass, marsh or mangrove habitats.

It is critical to measure movement of individuals if we are to understand better the role of so-called nursery habitats in the life cycle of marine organisms. Movement must be monitored from all types of habitat in which the juvenile is found, because the nursery role hypothesis focuses on the different types of habitat utilised by juveniles, and not just a selected subset of habitats (Beck et al. 2001). Determining which juvenile habitats contribute more per unit area to the production of individuals that recruit to adult populations will allow management and conservation efforts to focus on those habitats that make the greatest contribution to adult populations.
Acknowledgements. We thank E. Johnson for assistance in reviewing the crustacean literature. This work was conducted as part of the Nursery Roles Working Group supported by the National Centre for Ecological Analysis and Synthesis, a centre funded by NSF (Grant \#DEB-0072909), at the University of California, Santa Barbara. We thank all members of that working group, namely M. Beck, D. Childers, K. Heck, B. Halpern, C. Hays, T. Minello, R. Orth and M. Weinstein for discussions and comments. B.M.G. was funded by an Australian Research Council QEII fellowship. Order of co-authors is alphabetical.

\section{LITERATURE CITED}

Abello P, Macpherson E (1991) Distribution patterns and migration of Lithodes ferox (Filhol) (Anomura: Lithodidae) off Namibia. J Crustac Biol 11:261-268

Able KW (1999) Measures of juvenile fish habitat quality: examples from a National Estuarine Research Reserve. In: Benaka LR (ed) Fish habitat: essential fish habitat and rehabilitation. American Fisheries Society, Bethesda, p 134-147

Allen MJ, Herbinson KT (1990) Settlement of juvenile California halibut, Paralichthys californicus, along the coasts of Los Angeles, Orange, and San Diego counties in 1989. Calif Coop Ocean Fish Invest Rep 31:84-96

Beck MW, Heck KL, Able KW, Childers DL and 9 others (2001) The identification, conservation, and management of estuarine and marine nurseries for fish and invertebrates. BioScience 51:633-641

Bell JD, Worthington DG (1993) Links between estuaries and coastal rocky reefs in the lives of fishes from south-eastern Australia. In: Battershill CB, Schiel DR, Jones GP, Cresse RG, MacDiarmid AB (eds) Proceedings of the Second International Temperate Reef Symposium, January 7-10, 1992, Auckland. NIWA Marine, Wellington, p 85-91

Benfield MC, Bosschieter JR, Forbes AT (1990) Growth and emigration of Penaeus indicus H. Milne-Edwards (Crustacea: Decapoda: Penaeidae) in the St. Lucia Estuary, southern Africa. Fish Bull 88:21-28

Beukers JS, Jones GP, Buckley RM (1995) Use of implant microtags for studies on populations of small reef fish. Mar Ecol Prog Ser 125:61-66

Blaber SJM, Brewer DT, Salini JP (1989) Species composition and biomasses of fishes in different habitats of a tropical northern Australian estuary: their occurrence in the adjoining sea and estuarine dependence. Estuar Coast Shelf Sci 29:509-531

Blaber SJM, Brewer DT, Milton DA, Merta GS, Efizon D, Fry G, van der Velde T (1999) The life history of the protandrous tropical shad Tenualosa macrura (Alosinae: Clupeidae): fishery implications. Estuar Coast Shelf Sci 49: 689-701

Block BA, Dewar H, Farwell C, Prince ED (1998) A new satellite technology for tracking the movements of Atlantic bluefin tuna. Proc Natl Acad Sci USA 95:9384-9389

Bonneau JL, Thurow RF, Scarnecchia DL (1995) Capture, marking, and enumeration of juvenile bull trout and cutthroat trout in small, low-conductivity streams. N Am J Fish Manage 15:563-568

Booth JD (1979) North Cape-a 'nursery area' for the packhorse rock lobster, Jasus verreauxi (Decapoda: Palinuridae). NZ J Mar Freshw Res 13:521-528

Booth JD (1986) Recruitment of packhorse rock lobster Jasus verreauxi in New Zealand. Can J Fish Aquat Sci 43: $2212-2220$ 
Buckley RM, Blankenship HL (1990) Internal extrinsic identification systems: overview of implanted wire tags, otolith marks, and parasites. Am Fish Soc Symp 7:173-182

Buckley RM, West JE, Doty DC (1994) Internal micro-tag systems for marking juvenile reef fishes. Bull Mar Sci 55: 848-857

Campana SE (1999) Chemistry and composition of fish otoliths: pathways, mechanisms and applications. Mar Ecol Prog Ser 188:263-297

Campana SE, Gagne JA (1995) Cod stock discrimination using ICPMS elemental assays of otoliths. In: Secor DH, Dean JM, Campana SE (eds) Recent developments in fish otolith research. University of South Carolina Press, Columbia, p 671-691

Campana SE, Fowler AJ, Jones CM (1994) Otolith elemental fingerprinting for stock discrimination of Atlantic cod (Gadus morhua) using laser ablation ICPMS. Can J Fish Aquat Sci 51:1942-1950

Cappo M, Walters CJ, Lenanton RC (2000) Estimation of rates of migration, exploitation and survival using tag recovery data for western Australian 'salmon' (Arripis truttaceus: Arripidae: Percoidei). Fish Res 44:207-217

Carr MH (1991) Habitat selection and recruitment of an assemblage of temperate zone reef fishes. J Exp Mar Biol Ecol 146:113-137

Carr MH (1994) Effects of macroalgal dynamics on recruitment of a temperate reef fish. Ecology 75:1320-1333

Carr MH, Reed DC (1992) Conceptual issues relevant to marine harvest refuges: examples from temperate reef fishes. Can J Fish Aquat Sci 50:2019-2028

Cattrijsse A, Dankwa HR, Mees J (1997) Nursery function of an estuarine tidal marsh for the brown shrimp Crangon crangon. J Sea Res 38:109-121

Chong VC, Sasekumar A, Leh MUC, D'Cruz R (1990) The fish and prawn communities of a Malaysian coastal mangrove system, with comparisons to adjacent mud flats and inshore waters. Estuar Coast Shelf Sci 31:703-722

Chubb CF, Potter IC, Grant CJ, Lenanton RCJ, Wallace J (1981) Age structure, growth rates and movements of sea mullet, Mugil cephalus L., and yellow-eye mullet, Aldrichetta forsteri (Valenciennes), in the Swan-Avon river system, Western Australia. Aust J Mar Freshw Res 32: 605-628

Coles RG, Greenwood JG (1983) Seasonal movement and size distribution of three commercially important Australian prawn species (Crustacea: Penaeidae) within an estuarine system. Aust J Mar Freshw Res 34:727-743

Connell SD, Jones GP (1991) The influence of habitat complexity on postrecruitment processes in a temperate reef fish population. J Exp Mar Biol Ecol 151:271-294

Costello TJ, Allen DM (1966) Migrations and geographic distribution of pink shrimp, Penaeus duorarum, of the Tortugas and Sanibel grounds, Florida. Fish Bull Fish Wildl Serv 65:449-459

Courtney DL, Mortensen DG, Orsi JA, Munk KM (2000) Origin of juvenile Pacific salmon recovered from coastal southeastern Alaska identified by otolith thermal marks and coded wire tags. Fish Res 46:267-278

Coutant CC, Chen CH (1993) Strontium microstructure in scales of freshwater and estuarine striped bass (Morone saxatilis) detected by laser ablation mass spectrometry. Can J Fish Aquat Sci 50:1318-1323

Dahlgren CP, Eggleston DB (2000) Ecological processes underlying ontogenetic habitat shifts in coral reef fish. Ecology 81:2227-2240

de Pontual H, Lagardere F, Troadec H, Batel A, Desaunay Y, Koutsikopoulos C (2000) Otoliths imprinting of sole (Solea solea) from the Bay of Biscay: a tool to discriminate individuals from nursery origins? Oceanol Acta 23:497-513

Deegan LA (1990) Effects of estuarine environmental conditions on population dynamics of young-of-the-year Gulf menhaden. Mar Ecol Prog Ser 68:195-205

Deegan LA (1993) Nutrient and energy transport between estuaries and coastal marine ecosystems by fish migration. Can J Fish Aquat Sci 50:74-79

Dewey MR, Zigler SJ (1996) An evaluation of fluorescent elastomer for marking bluegills in experimental studies. Prog Fish-Cult 58:219-220

DiBacco C, Levin LA (2000) Development and application of elemental fingerprinting to track the dispersal of marine invertebrate larvae. Limnol Oceanogr 45:871-880

Dorf BA, Powell JC (1997) Distribution, abundance, and habitat characteristics of juvenile tautog (Tautoga onitis, Family Labridae) in Narragansett Bay, Rhode Island, 1988-1992. Estuaries 20:589-600

Edmonds JS, Moran MJ, Caputi N (1989) Trace element analysis of fish sagittae as an aid to stock identification: pink snapper (Chrysophrys auratus) in Western Australian waters. Can J Fish Aquat Sci 46:50-54

Edmonds JS, Caputi N, Morita M (1991) Stock discrimination by trace-element analysis of otoliths of orange roughy (Hoplostethus atlanticus), a deep-water marine teleost. Aust J Mar Freshw Res 42:383-389

Edmonds JS, Lenanton RCJ, Caputi N, Morita M (1992) Trace elements in the otoliths of yellow-eye mullet (Aldrichetta forsteri) as an aid to stock identification. Fish Res 13:39-51

Eggleston DB (1995) Recruitment in Nassau grouper Epinephelus striatus: post-settlement abundance, microhabitat features, and ontogenetic habitat shifts. Mar Ecol Prog Ser 124:9-22

Eggleston DB, Dahlgren CP (2001) Distribution and abundance of Caribbean spiny lobster in the Key West National Wildlife Refuge: relationship to habitat features and impact of an intensive recreational fishery. Mar Freshw Res 52:1567-1576

Ennevor BC, Beames RM (1993) Use of lanthanide elements to mass mark juvenile salmonids. Can J Fish Aquat Sci 50: 1039-1044

Fairweather PG (1991) Implications of 'supply-side' ecology for environmental assessment and management. Trends Ecol Evol 6:60-63

Fairweather PG, Quinn GP (1993) Seascape ecology: the importance of linkages. In: Battershill CB, Schiel DR, Jones GP, Cresse RG, MacDiarmid AB (eds) Proceedings of the Second International Temperate Reef Symposium, January 7-10, 1992, Auckland. NIWA Marine, Wellington, p 77-83

Frederick JL (1997a) Post-settlement movement of coral reef fishes and bias in survival estimates. Mar Ecol Prog Ser 150:65-74

Frederick JL (1997b) Evaluation of fluorescent elastomer injection as a method for marking small fish. Bull Mar Sci 61:399-408

Freire J, Gonzalez-Gurriaran E (1998) New approaches to the behavioural ecology of decapod crustaceans using telemetry and electronic tags. Hydrobiologia 371/372: 123-132

Fry B (1981) Natural stable carbon isotope tag traces Texas shrimp migrations. Fish Bull 79:337-345

Fry B (1983) Fish and shrimp migrations in the northern Gulf of Mexico analyzed using stable $\mathrm{C}, \mathrm{N}$ and $\mathrm{S}$ isotope ratios. Fish Bull 81:789-801

Fry B, Mumford PL, Robblee MB (1999) Stable isotope studies of pink shrimp (Farfantepenaeus duorarum Burkenroad) 
migrations on the southwestern Florida shelf. Bull Mar Sci 65:419-430

Fukuwaka M, Suzuki T (1998) Role of a riverine plume as a nursery area for chum salmon Oncorhynchus keta. Mar Ecol Prog Ser 173:289-297

Gillanders BM (1997a) Comparison of growth rates between estuarine and coastal reef populations of Achoerodus viridis (Pisces: Labridae). Mar Ecol Prog Ser 146:283-287

Gillanders BM (1997b) Patterns of abundance and size structure in the blue groper Achoerodus viridis (Pisces: Labridae): evidence of links between estuaries and coastal reefs. Environ Biol Fish 49:153-173

Gillanders BM (2002) Connectivity between juvenile and adult fish populations: do adults remain near their recruitment estuaries? Mar Ecol Prog Ser 240:215-223

Gillanders BM, Kingsford MJ (1993) Abundance patterns of Achoerodus viridis (Pisces: Labridae) on estuarine and exposed rocky reefs: possible linkages. In: Battershill $\mathrm{CB}$, Schiel DR, Jones GP, Cresse RG, MacDiarmid AB (eds) Proceedings of the Second International Temperate Reef Symposium, January 7-10, 1992, Auckland. NIWA Marine, Wellington, p 93-98

Gillanders BM, Kingsford MJ (1996) Elements in otoliths may elucidate the contribution of estuarine recruitment to sustaining coastal reef populations of a temperate reef fish. Mar Ecol Prog Ser 141:13-20

Gillanders BM, Kingsford MJ (2000) Elemental fingerprints of otoliths of fish may distinguish estuarine 'nursery' habitats. Mar Ecol Prog Ser 201:273-286

Gilliam JF, Fraser DF (1987) Habitat selection under predation hazard: test of a model with foraging minnows. Ecology 68:1856-1862

Griffiths MH (1996) Life history of the dusky kob Argyrosomus japonicus (Sciaenidae) off the east coast of South Africa. S Afr J Mar Sci 17:135-154

Grimes CB, Able KW, Jones RS (1986) Tilefish, Lopholatilus chamaeleonticeps, habitat, behaviour and community structure in Mid-Atlantic and southern New England waters. Environ Biol Fish 15:273-292

Groot C, Margolis L (1991) Pacific salmon life histories. University of British Columbia Press, Vancouver

Gunderson DR, Armstrong DA, Shi YB, McConnaughey RA (1990) Patterns of estuarine use by juvenile English sole (Parophyrys vetulus) and dungeness crab (Cancer magister). Estuaries 13:59-71

Henriques M, Almada VC (1998) Juveniles of non-resident fish found in sheltered rocky subtidal areas. J Fish Biol 52: 1301-1304

Hines AH, Wolcott TG, Gonzalez-Gurriaran E, GonzalezEscalante JL, Freire J (1995) Movement patterns and migrations in crabs: telemetry of juvenile and adult behaviour in Callinectes sapidus and Maja squinado. J Mar Biol Assoc UK 75:27-42

Hobson KA (1999) Tracing origins and migration of wildlife using stable isotopes: a review. Oecologia 120: $314-326$

Hyland SJ, Hill BJ, Lee CP (1984) Movement within and between different habitats by the portunid crab Scylla serrata. Mar Biol 80:57-61

Jones GP (1984) Population ecology of the temperate reef fish Pseudolabrus celidotus Bloch and Schneider (Pisces: Labridae). 1. Factors influencing recruitment. J Exp Mar Biol Ecol 75:257-276

Jones GP, Milicich MJ, Emslie MJ, Lunow C (1999) Selfrecruitment in a coral reef fish population. Nature 402: 802-804

Kalish JM (1990) Use of otolith microchemistry to distinguish the progeny of sympatric anadromous and non-anadromous salmonids. Fish Bull 88:657-666

Kanciruk P, Herrnkind W (1978) Mass migration of spiny lobster, Panulirus argus (Crustacea: Palinuridae): behavior and environmental correlates. Bull Mar Sci 28:601-623

Kennedy BP, Blum JD, Folt CL, Nislow KH (2000) Using natural strontium isotopic signatures as fish markers: methodology and application. Can J Fish Aquat Sci 57:2280-2292

Kerstan M (1991) The importance of rivers as nursery grounds for 0- and 1-group flounder (Platichthys flesus L.) in comparison to the Wadden Sea. Neth J Sea Res 27:353-366

Klaoudatos S, Tsevis N, Conides A (1992) Studies on migratory movements of the prawn Penaeus kerathurus (Forskal, 1775) at Amvrakikis Gulf, Western Greece. PSZN I: Mar Ecol 13:133-147

Kneib RT (1997) The role of tidal marshes in the ecology of estuarine nekton. Oceanogr Mar Biol Annu Rev 35:163-220

Koenig CC, Coleman FC (1998) Absolute abundance and survival of juvenile gags in seagrass beds of the northeastern Gulf of Mexico. Trans Am Fish Soc 127:44-55

Koutsikopoulos C, Dorel D, Desaunay Y (1995) Movement of sole (Solea solea) in the Bay of Biscay: coastal environment and spawning migration. J Mar Biol Assoc UK 75:109-126

Kramer SH (1991) Growth, mortality, and movements of juvenile California halibut Paralichthys californicus in shallow coastal and bay habitats of San Diego County, California. Fish Bull 89:195-207

Kraus SD (1998) The telemetering of marine animals: developing a new paradigm. Mar Technol Soc J 32:108-109

Kroger RL, Guthrie JF (1973) Migrations of tagged juvenile Atlantic menhaden. Trans Am Fish Soc 2:417-422

Lipcius RN, Eggleston DB (2000) Introduction: ecology and fishery biology of spiny lobsters. In: Phillips BF, Cobb JS, Kittaka J (eds) Spiny lobster management. Blackwell Scientific Publications, Oxford, p 1-42

MacKenzie K, Abaunza P (1998) Parasites as biological tags for stock discrimination of marine fish: a guide to procedures and methods. Fish Res 38:45-56

Mathews SB, Barker MW (1983) Movements of rockfish (Sebastes) tagged in northern Puget Sound, Washington. Fish Bull 82:916-922

McCormick MI (1989) Spatio-temporal patterns in the abundance and population structure of a large temperate reef fish. Mar Ecol Prog Ser 53:215-225

McCormick SD, Hansen LP, Quinn TP, Saunders RL (1998) Movement, migration, and smolting of Atlantic salmon (Salmo salar). Can J Fish Aquat Sci 55:77-92

Milton DA, Chenery SP (2001) Sources and uptake of trace metals in otoliths of juvenile barramundi (Lates calcarifer). J Exp Mar Biol Ecol 264:47-65

Montgomery SS (1990) Movements of juvenile eastern king prawns, Penaeus plebejus, and identification of stock along the east coast of Australia. Fish Res 9:189-208

Moore R, Reynolds LF (1982) Migration patterns of barramundi, Lates calcarifer (Bloch), in Papua New Guinea. Aust J Mar Freshw Res 33:671-682

Moore R, MacFarlane JW (1984) Migration of the ornate rock lobster, Panulirus ornatus (Fabricius) in Papua New Guinea. Aust J Mar Freshw Res 35:197-212

Morton RM, Halliday I, Cameron D (1993) Movement of tagged juvenile tailor (Pomatomus saltatrix) in Moreton Bay, Queensland. Aust J Mar Freshw Res 44:811-816

Muller VK (1982) Seaward migration of juvenile fish species to the Bothnian Sea. Arch Hydrobiol 95:271-282

Nicholson WR (1978) Movements and population structure of Atlantic menhaden indicated by tag returns. Estuaries 1: $141-150$ 
Norris KS (1963) The functions of temperature in the ecology of the percoid fish Girella nigricans (Ayres). Ecol Monogr 33:23-62

O'Brien CJ (1994) Population dynamics of juvenile tiger prawns Penaeus esculentus in south Queensland, Australia. Mar Ecol Prog Ser 104:247-256

Olson RE, Pratt I (1973) Parasites as indicators of English sole (Parophrys vetulus) nursery grounds. Trans Am Fish Soc 102:405-411

Patterson WP, Smith GR, Lohmann KC (1993) Continental paleothermometry and seasonality using the isotopic composition of aragonitic otoliths of freshwater fishes. Geophys Monogr 78:191-202

Phillips BF (1983) Migrations of pre-adult western rock lobsters, Panulirus cygnus, in Western Australia. Mar Biol 76: 311-318

Proctor CH, Thresher RE, Gunn JS, Mills DJ, Harrowfield IR, Sie SH (1995) Stock structure of the southern bluefin tuna Thunnus maccoyii: an investigation based on probe microanalysis of otolith composition. Mar Biol 122:511-526

Riera P, Montagna PA, Kalke RD, Richard P (2000) Utilization of estuarine organic matter during growth and migration by juvenile brown shrimp Penaeus aztecus in a south Texas estuary. Mar Ecol Prog Ser 199:205-216

Roa R, Gallardo VA, Ernst B, Baltazar M, Canete JI, EnriquezBrionnes S (1995) Nursery ground, age structure and abundance of juvenile squat lobster Pleuroncodes monodon on the continental shelf off central Chile. Mar Ecol Prog Ser 116:47-54

Rogers SI (1993) The dispersion of sole, Solea solea and plaice, Pleuronectes platessa within and away from a nursery ground in the Irish Sea. J Fish Biol 43(Suppl A): 275-288

Rooker JR, Dennis GD (1991) Diel, lunar and seasonal changes in a mangrove fish assemblage off southwestern Puerto Rico. Bull Mar Sci 49:684-698

Royce WF, Smith LS, Hart AC (1968) Models of oceanic migrations of Pacific salmon and comments on guidance mechanisms. Fish Bull Fish Wildl Serv 66:441-462

Ruello NV (1975) Geographical distribution, growth and breeding migration of the eastern Australian king prawn Penaeus plebejus Hess. Aust J Mar Freshw Res 26: 343-354

Ruello NV (1977) Migration and stock studies on the Australian school prawn Metapenaeus macleayi. Mar Biol 41: 185-190

Russell DJ, Garrett RN (1985) Early life history of barramundi, Lates calcarifer (Bloch), in north-eastern Queensland. Aust J Mar Freshw Res 36:191-201

Russell DJ, Garrett RN (1988) Movements of juvenile barramundi, Lates calcarifer (Bloch), in north-eastern Queensland. Aust J Mar Freshw Res 39:117-123

Salman SD, Ali MH, Al-Adhub AHY (1990) Abundance and seasonal migrations of the penaeid shrimp Metapenaeus affinis (H. Milne-Edwards) within Iraqi waters. Hydrobiologia 196:79-90

Secor DH (1992) Application of otolith microchemistry analysis to investigate anadromy in Chesapeake Bay striped bass Morone saxatilis. Fish Bull 90:798-806

Sheaves M (1995) Large lutjanid and serranid fishes in tropical estuaries: are they adults or juveniles? Mar Ecol Prog Ser 129:31-40

Shlossman PA, Chittenden ME (1981) Reproduction, movements, and population dynamics of the sand seatrout, Cynoscion arenarius. Fish Bull 79:649-669

Sibert JR, Nielson JL (2001) Electronic tagging and tracking in marine fisheries. Kluwer Academic Publishers, Dordrecht
Skewes TD, Dennis DM, Pitcher CR, Long BG (1997) Age structure of Panulirus ornatus in 2 habitats in Torres Strait, Australia. Mar Freshw Res 48:745-750

Somers IF, Kirkwood GP (1991) Population ecology of the grooved tiger prawn, Penaeus semisulcatus, in the northwestern Gulf of Carpentaria, Australia: growth, movement, age structure and infestation by the bopyrid parasite Epipenaeon ingens. Aust J Mar Freshw Res 42:349-367

Staples DJ (1979) Seasonal migration patterns of postlarval and juvenile banana prawns, Penaeus merguiensis de Man, in the major rivers of the Gulf of Carpentaria, Australia. Aust J Mar Freshw Res 30:143-157

Staples DJ (1980) Ecology of juvenile and adolescent banana prawns, Penaeus merguiensis, in a mangrove estuary and adjacent offshore area of the Gulf of Carpentaria. I. Immigration and settlement of postlarvae. Aust J Mar Freshw Res 31:635-652

Staples DJ, Vance DJ (1986) Emigration of juvenile banana prawns Penaeus merguiensis from a mangrove estuary and recruitment to offshore areas in the wet-dry tropics of the Gulf of Carpentaria, Australia. Mar Ecol Prog Ser 27: $239-252$

Stoner AW (1989) Winter mass migration of juvenile queen conch Strombus gigas and their influence on the benthic environment. Mar Ecol Prog Ser 56:99-104

Stoner AW, Lipcius RN, Marshall LS, Bardales AT (1988) Synchronous emergence and mass migration in juvenile queen conch. Mar Ecol Prog Ser 49:51-55

Swearer SE, Caselle JE, Lea DW, Warner RR (1999) Larval retention and recruitment in an island population of a coral-reef fish. Nature 402:799-802

Symonds DJ, Rogers SI (1995) The influence of spawning and nursery grounds on the distribution of sole Solea solea (L.) in the Irish Sea, Bristol Channel and adjacent areas. J Exp Mar Biol Ecol 190:243-261

Szedlmayer ST, Able KW (1993) Ultrasonic telemetry of age-0 summer flounder, Paralichthys dentatus, movements in a southern New Jersey estuary. Copeia 1993:728-736

Tabb DC, Dubrow DL, Jones AE (1962) Studies on the biology of the pink shrimp, Penaeus duorarum Burkenroad, in Everglades National Park, Florida. State of Florida Board of Conservation, Technical Series No. 37

Thorrold SR, Jones CM, Swart PK, Targett TE (1998) Accurate classification of juvenile weakfish Cynoscion regalis to estuarine nursery areas based on chemical signatures in otoliths. Mar Ecol Prog Ser 173:253-265

Thorrold SR, Latkoczy C, Swart PK, Jones CM (2001) Natal homing in a marine fish metapopulation. Science 291: 297-299

Thresher RE, Proctor CH, Gunn JS, Harrowfield IR (1994) An evaluation of electron-probe microanalysis of otoliths for stock delineation and identification of nursery areas in a southern temperate groundfish, Nemadactylus macropterus (Cheilodactylidae). Fish Bull 92:817-840

Underwood AJ, Fairweather PG (1989) Supply-side ecology and benthic marine assemblages. Trends Ecol Evol 4:16-20

Urawa S, Kawana M, Anma G, Kamei Y and 5 others (2000) Geographic origin of high-seas chum salmon determined by genetic and thermal otolith markers. North Pac Anadromous Fish Comm Bull 2:283-290

Vance DJ, Haywood MDE, Heales DS, Kenyon RA, Loneragan NR (1998) Seasonal and annual variation in abundance of postlarval and juvenile banana prawns Penaeus merguiensis and environmental variation in two estuaries in tropical northeastern Australia: a six year study. Mar Ecol Prog Ser 163:21-36

van Montfrans J, Ryer CH, Orth RJ (1991) Population dynam- 
ics of blue crabs Callinectes sapidus Rathbun in a lower Chesapeake Bay tidal marsh creek. J Exp Mar Biol Ecol 153:1-14

Volk EC, Schroder SL, Grimm JJ (1999) Otolith thermal marking. Fish Res 43:205-219

Weber PK, Hutcheon ID, McKeegan KD, Ingram BL (2002) Otolith sulfur isotope method to reconstruct salmon (OnCorhynchus tshawytscha) life history. Can J Fish Aquat Sci 59:587-591

Weinstein MP, Heck KL (1979) Ichthyofauna of seagrass meadows along the Caribbean coast of Panama and in the Gulf of Mexico: composition, structure and community ecology. Mar Biol 50:97-107

West GJ, Stevens JD (2001) Archival tagging of school shark, Galeorhinus galeus, in Australia: initial results. Environ Biol Fish 60:283-298

Editorial responsibility: Otto Kinne (Editor),

Oldendorf/Luhe, Germany
Wicker AM, Currin BM, Miller JM (1988) Migration of brown shrimp in nursery areas of Pamlico Sound, North Carolina, as indicated by changes in length-frequency distributions. Trans Am Fish Soc 117:92-94

Williams HH, MacKenzie K, McCarthy AM (1992) Parasites as biological indicators of the population biology, migrations, diet, and phylogenetics of fish. Rev Fish Biol Fish 2: $144-176$

Wolcott TG (1995) New options in physiological and behavioural ecology through multichannel telemetry. J Exp Mar Biol Ecol 193:257-275

Yamashita Y, Otake T, Yamada H (2000) Relative contributions from exposed inshore and estuarine nursery grounds to the recruitment of stone flounder, Platichthys bicoloratus, estimated using otolith $\mathrm{Sr}: \mathrm{Ca}$ ratios. Fish Oceanogr 9:316-327

Submitted: January 15, 2002; Accepted: September 24, 2002 Proofs received from author(s): January 6, 2003 